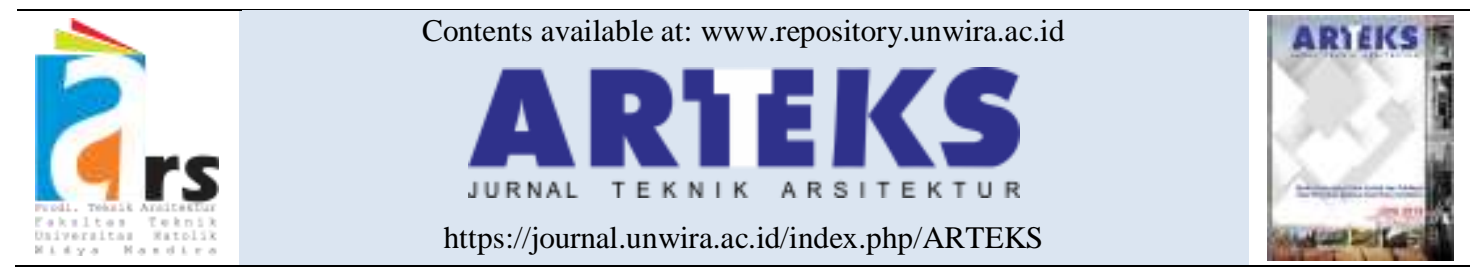

Research paper

doi: $10.30822 /$ arteks.v6i3.714

\title{
Identification of physical changes in the house in Samin Blora community based on Habraken's theory
}

\author{
Badrut Anggara Putra* ${ }^{*}$, Agung Budi Sarjono, Edward E. Pandelaki \\ Department of Architecture, Universitas Diponegoro \\ Jl. Prof. Soedarto, Kampus Undip Tembalang, Semarang, Jawa Tengah, Indonesia, 50275 CrossMark
}

\begin{tabular}{|c|c|}
\hline ARTICLE INFO & ABSTRACT \\
\hline $\begin{array}{l}\text { Article history: } \\
\text { Received October } 23,2020 \\
\text { Received in revised form Nov. 12, } 2020 \\
\text { Accepted June } 28,2021 \\
\text { Available online December } 01,2021\end{array}$ & $\begin{array}{l}\text { Cultural transformation is one of the Habraken Architectural } \\
\text { theories, which involves three categories of change, namely } \\
\text { physical, spatial, and cultural. The development of modern culture } \\
\text { in the residential area of the Samin community in Blora Regency has } \\
\text { an impact on the emergence of physical changes in the shelter. }\end{array}$ \\
\hline $\begin{array}{l}\text { *Corresponding author: Badrut A. Putra } \\
\text { Department Architecture, Univesitas } \\
\text { Diponegoro, Indonesia } \\
\text { Email: panggara303@ @mail.com } \\
\text { ORCID: https://orcid.org/0000-0002-0954- } \\
3218\end{array}$ & $\begin{array}{l}\text { Hence, this study aimed to identify the physical changes and the } \\
\text { aspects affecting them. There are six basic aspects in the theory of } \\
\text { physical change proposed by Habraken, namely Body \& Utensils, } \\
\text { Furniture, Partitioning, building elements, roads, and Major Artery. } \\
\text { A deductive rationalistic approach and qualitative descriptive } \\
\text { methods were used in this study for collecting data through } \\
\text { interviews with the Samin community in Blora Regency, for field } \\
\text { observations, and analyzing the physical changes of the object. This } \\
\text { analysis refers to the concept of changing the cultural structure of } \\
\text { Habraken. Consequently, the conclusion showed that the people in } \\
\text { Blora still adhere to the teachings of samin. Among the six objects, } \\
\text { only two modern materials were used, namely glass and ceramic } \\
\text { floors. Moreover, body utensils and building elements were the } \\
\text { aspects that mostly influence the changes that occurred. }\end{array}$ \\
\hline
\end{tabular}

\section{Introduction}

Indonesia is a country with many tribes and regional languages. According to the statistical data (BPS) for 2010, there are 1331 ethnic groups in the country. Furthermore, the society consists of those that are familiar with foreign cultures and those that have not touched their life values (Zuchdi 2009). The State of Indonesia is a container and unifier of various ethnic groups stretching from Sabang to Merauke region (Sri Pinasti and Lestari 2018). Each tribe has a tradition whose values or rules are obeyed over a long time and passed down orally between generations (Rapoport 1983; Subroto 2019). One of those that have followed the times and technology today is the Samin tribe, also known as the Samin Community (Purnomo 2017).
In addition, the community is based on the teachings of Saminism, whose origin came from a character named Samin Surosentiko, born in 1859 in Ploso Kedhiren Village, Randublatung District, Blora Regency (Rosyid 2010).

They are known for being innocent, honest, and very closed in ancient times, and even exiled themselves in forests far from residential areas (Mustinda 2021). The Samin community began to open up and mingle with other people from independence, until electricity program entered the village in 1990 (Munawaroh, Ariani, and Suwarno 2015).

The role of the community is very big in controlling the changes that occur in the built environment living in the place (Bukit, Hanan, and Wibowo 2012; Widodo 2019; Bawole 2020). Traditional houses in rural areas also undergo development and change (transformation) 
towards modernity (Sardjono and Nugroho 2015). Basically, the changes that occur in the built environment are always directly influenced by socio-cultural and the activity patterns of residents or communities living in the place (Bukit, Hanan, and Wibowo 2012).

According to Habraken, transformation or change is the addition, reduction, and displacement of a primary or main element to the built environment (Habraken 1998).

This phenomenon occurs in a settlement because of the strong influence of various changes in the cultural fabric of the society. Also, the existence of acculturation, enculturation, cultural synthesis, and dialogue processes that arise within certain groups can cause a shift or development of the values and social interaction of a particular culture (Sachari and Sunarya 2001). Transformation of cultural structures can be observed based on the aspects beyond control, which include how to share forms, words and forms, and patterns (Sesotyaningtyas, Pratiwi, and Setyono 2015).

Basically, the transformation of a particular community can occur gradually through a process that lasts for centuries with all its richness and complexity (Habraken 1998). The built environment consists of physical forms such as buildings, roads or infrastructure, and the people living in the area (Pangarso, Sugiarto, and Anindyasarathi 2017). Just like the Samin people, a tribe on the island of Java, that adapted and transformed from a society that is initially isolated, and become open to outside culture.

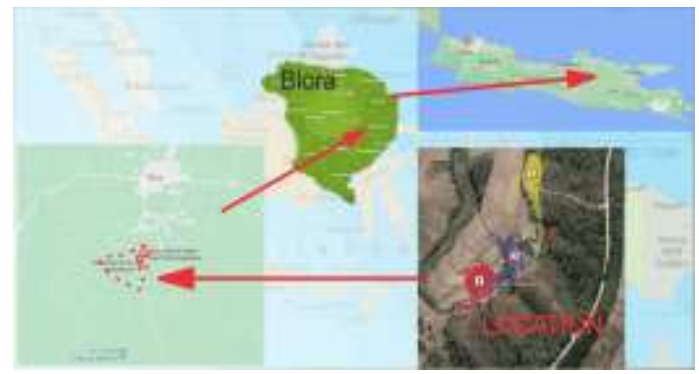

Figure 1. Village area of Samin Klopoduwur Blora

The shape of the Samin Blora village is characterized by a cluster or group as shown in figure 1 . With this concept, many activities from the society are centralized and mutually open. The community was originally an association of Javanese tribes that had the teachings of Saminism, and also built settlements in the middle of the forest to avoid conflict with the Dutch government. Furthermore, they undergo a transition period to a modern society, which is manifested in "associative" and "dissociative" interactions. The associative form is cooperation, while the dissociative is social jealousy and misunderstanding (Huda and Mukti Wibowo 2013). In an effort to identify the changes that have occurred, traditional Javanese architectural books were referred to, such as Jogyakarta Traditional Architecture, written by Dakung Sugiarto (Dakung 1982).

The problem that arose regarding the change of occupancy in the Samin community houses in Blora was the reason for the transformation in the shape of the dwelling and the physical aspects responsible for it. Therefore, this study was conducted to determine the physical changes in the residential area of the Samin community and the aspects that are most dominant in it.

\section{Method}

A deductive rationalistic approach with a qualitative descriptive method was used in this study to determine how to find, collect, process, and analyze the data (Sugiyono 2019). The deductive approach was chosen because this study is based on the knowledge of the Habraken Cultural Transformation theory.

Consequently, the stages carried out include:

1. Preparation stage: This entails collecting literature (Habraken culture transformation theory, traditional architecture, and conservation of Eko Budihardjo architecture, Koentjaraningrat Javanese culture), determining the theme to be studied, and choosing a theme based on existing phenomena that have not been studied.

2. Data collection stage: A survey of building physical data was conducted using written notes or sketches, and interviews with informants. The source selection is purposive, and the resources are the houses in the core area of the Samin Blora community that has undergone physical changes.

3. Analysis stage: The analysis was carried out briefly by identifying 6 categories of physical changes from Habraken's theory (body utensil, furniture, Partioning, Building Elements, Roads, and Major Artery) and digitizing the sketches with AutoCAD software. The results 
of the processing are in the form of site plan, looks, and plans.

4. Conclusion stage: Based on the analysis, the results showed that there were physical changes and the most dominant aspects based on Habraken's theory were body utensils and building elements.

\section{Result and discussion}

1. The residential area of the Klopoduwur Blora Samin community

The village of Karangpace Klopoduwur is the first residential area considered, because the house of Samin community leader, Mr. Samin Surosentiko is situated there. Over time, the communities were scattered in several places with 7 distribution points namely Blora (the biggest), Grobogan, Pati, Kudus, Jepara, Tuban, and Bojonegoro (Sawunggaling 2020).

Since 2016, Dusun Karangpace has been recognized as a tourist village destination by the Blora district government (Poerwanto 2019). Hence, the government seeks to develop and preserve existing cultural heritage, by establishing Klopodhuwur as a tourist village. The stipulation is contained in the 2014-2028 Blora Regency Regional Tourism Development Master Plan, and the Blora Regency Regional Regulation Number 18 of 2011, Concerning Blora Regency Spatial Planning 2011-2031.

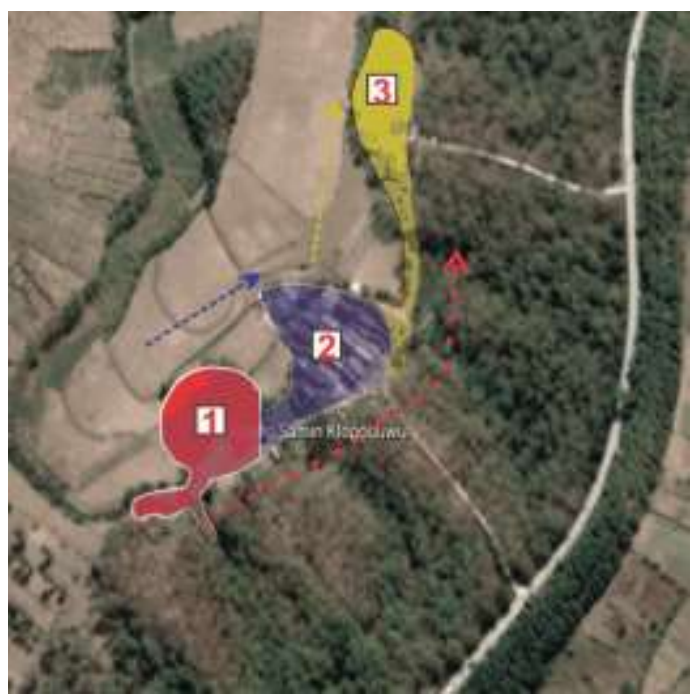

Figure 2. Path, circulation
According to Lasio's information, Samin Blora Village is divided into 3 regions, where region 1 is the first occupied area, then continues to region 2 and 3 as the last area, as shown in figure 2 .

2. Identification of changes to the Samin Blora community house

In this study, area 1 is the first known place of teaching in samin as shown in figure 2. This location has 12 housing units, consisting of 1 pendhopo unit, 10 housing units, and 1 balé unit. The house in the Samin community is srotong, which is one type of Javanese traditional house. The layout of the house is mostly divided into two types, namely the house divided into two and three (Tjahjono 1983). Among the 10 housing units in area 1 , srotong are used in only 6 , while the form of a village house are used in the rest. The location of the housing unit to be inspected is shown in figure 3 , and the explanation was given as follows.

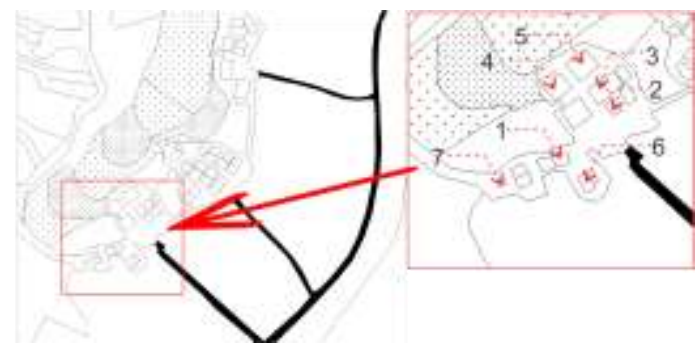

Figure 3. Research location of Samin community house

\section{House 1: Lasio}

A form of Lasio's house plan built in 2010 whose shape does not characterize a srotong but a village house is shown in figure 4 . The shape of the house with supporting poles is on the side of the building without supporting poles (saka guru) in the middle, as seen in figure 5. 


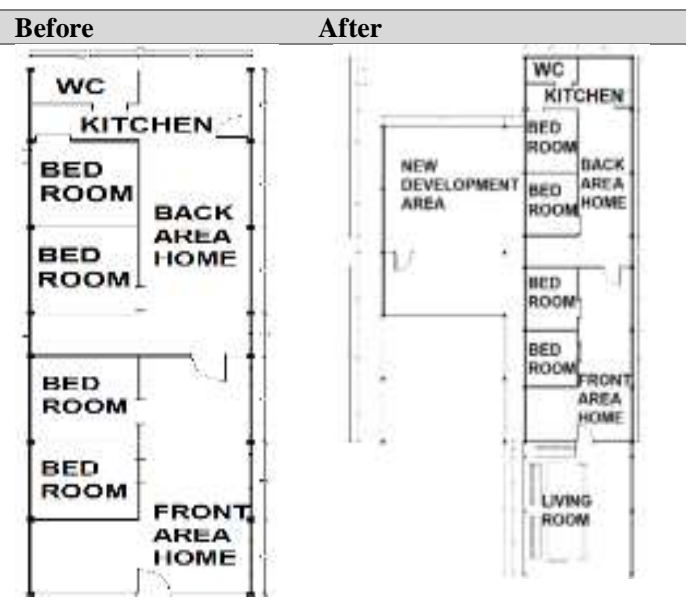

Figure 4. Comparison of Lasio's house plans

A form of Lasio's house plan built in 2010 whose shape does not characterize a srotong but a village house is shown in figure 4 . The shape of the house with supporting poles is on the side of the building without supporting poles (saka guru) in the middle, as seen in figure 5.

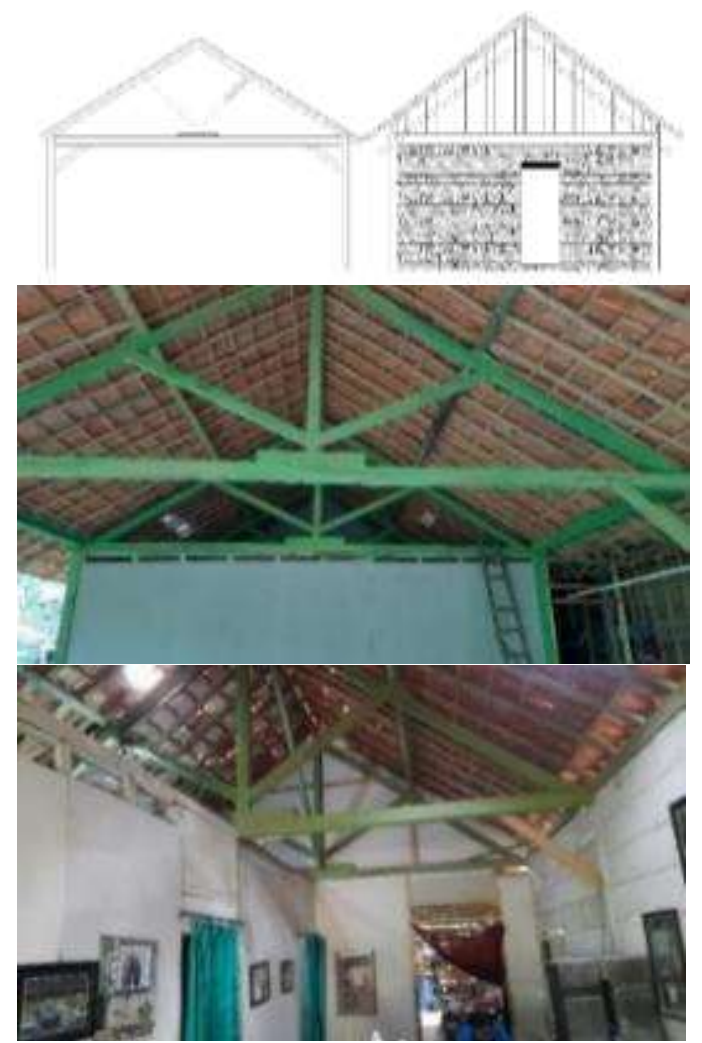

Figure 5. Shape of Lasio's house
In the middle, there are 4 bedrooms, while the back consists of a pawon known as kitchen as well as a wood fireplace for cooking. The walls of this house are made of wooden planks, while the back consists of woven bamboo. Furthermore, the floor was made with a combination of brick and cement. Moreover, brick and cement floors were used as a form of assistance from one of the local governments and an expression of gratitude to Lasio. But the floor was preferred to the ground because of the saying, "menungso iku sejatine asale saka lemah, balike yo nang lemah" which means "humans come from the ground, and also return to the ground". At the front, windows are on the right and left, while the back has 2 doors that lead to the outside of the building.

\section{House 2: Marsi}

A form of Marsi's house plan is shown in figure 6 , and is divided into 3 area segments, namely front, center, and back. The front part is used as the terrace and gathering space, while the middle is used as an empty area and bedroom, also the empty area is used to store crops. The back is used as an area for cattle sheds, kitchens, and bathrooms. Hence, this house is an example of a single srotong with no additional intersection building at the back or side of the house.

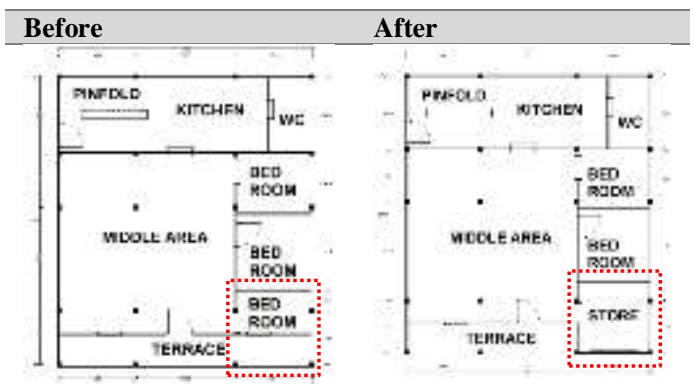

Figure 6. Comparison of Marsi's house plans

Figure 7 shows the front view of Marsi's house, with the addition of a stall as part of the children's business. In addition, a stone foundation is used and the height of the front porch is not more than $165 \mathrm{~cm}$ hence, it looks very short. Meanwhile, the inside of the house has a height of about 2-3 meters without a ceiling as seen in figure 8 . 


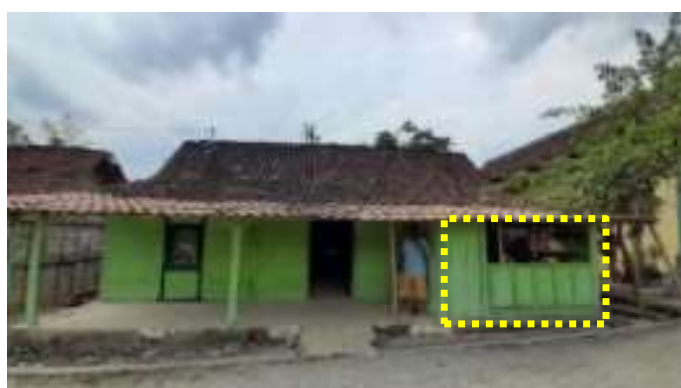

Figure 7. Front view of Marsi's house

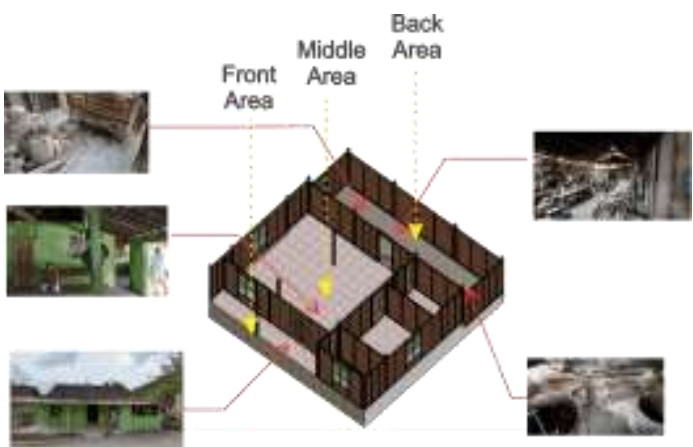

Figure 8. Current condition of Marsi's house

House 3: Jami

Jami is an elderly resident of Samin, whose age is over 90 years and also older than Lasio. The Jami's house is in the form of srotong with an area of $70 \mathrm{~m}^{2}$. In terms of space, no changes have occurred since the house was built as seen in figure 9.

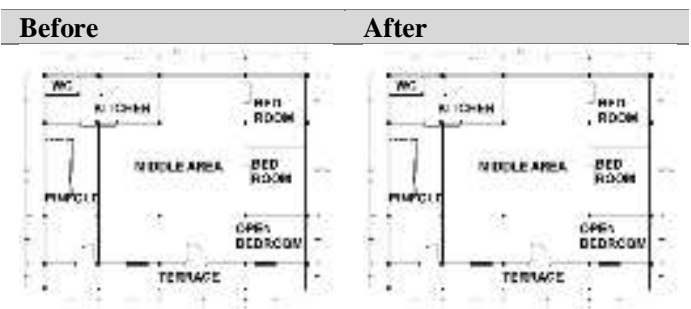

Figure 9. Comparison of Jami's house plans

Before it was painted green, the house was brown, with a dirt floor. Stone and cement floors were used around the end of 2017. According to the teachings of samin, stone and cement can be used as house floor, because they are still made of soil. Therefore, it does not violate the teachings of samin itself.

There are not much space division, from front to the back, in the interior of the building, however, it is only divided at the side with two bedrooms, while the front is used as an open bedroom. Basically, many family activities are carried out in the middle and terrace of the building. But the kitchen section is next and the livestock cage is located there as seen in figure 10 .

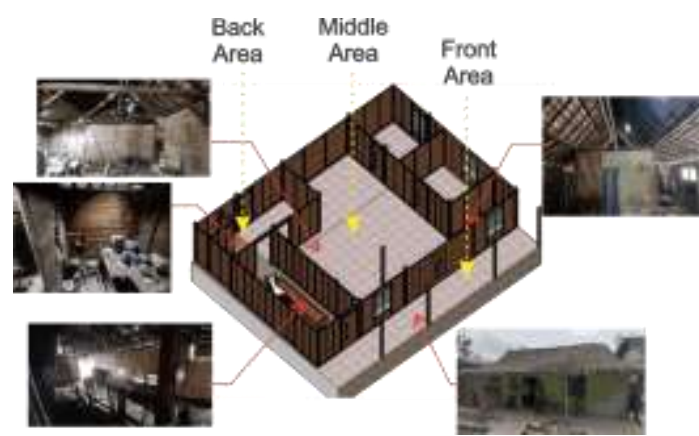

Figure 10. Current condition of Jami's house

House 4: Lapi

Lapi's house is one of the modern houses in the Samin Klopoduwur Village. This is because, modern materials are used for its shape as seen from outside. Being in the form of a village house with gable, it has a cross-section facing the East. Lapi built a house in front of the old one after getting married, and faced it to the North. Just like the old building, the front window doors were moved to the side that also faced north. The part of Lapi's house can be seen in figure 12.

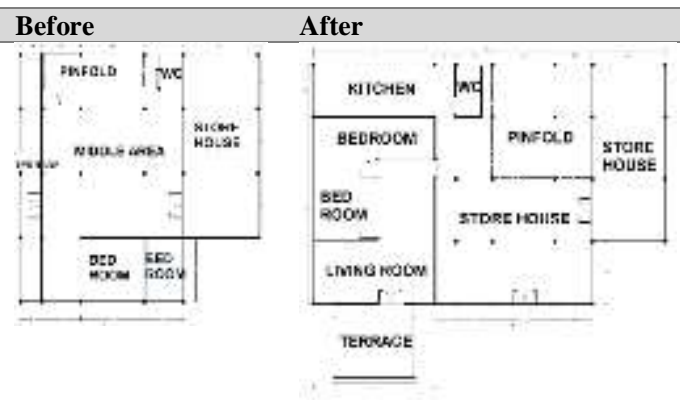

Figure 11. Comparison of Lapi's house plans 


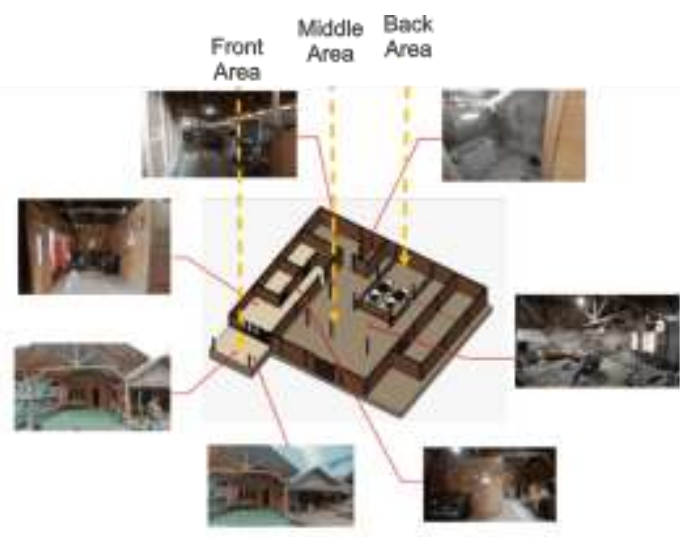

Figure 12. Lapi's house condition now

A variety of more modern materials were used in the new house, namely ceramics, half-brick walls, and stronger wooden planks as shown in figure 12. The space in this house was simply divided into terrace, living room, 2 rooms, while the back was used as a kitchen and bathroom.

Moreover, gable structure and hanging columns were used in the house roof, meaning that the load is conveyed directly to the right and left side walls columns of the building. In contrast to the cross-sectional house building, the roof was backed by the 4 saka guru like a Joglo house. A clean processing system is used in the house, also, the closet and water tub are made of ceramic and brick.

\section{House 5: Pardji}

The house plan of Pardji is a srotong shape facing south as shown in figure 13. Over time, the orientation of the building was changed to the west, thereby facing that of Lapi. Basically, the house has an area of $126 \mathrm{~m}^{2}$ and 2 building masses in it.

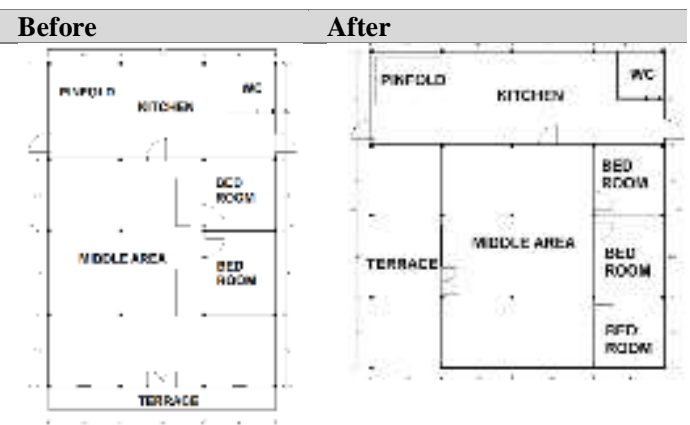

Figure 13. Comparison of Pardji's house plans

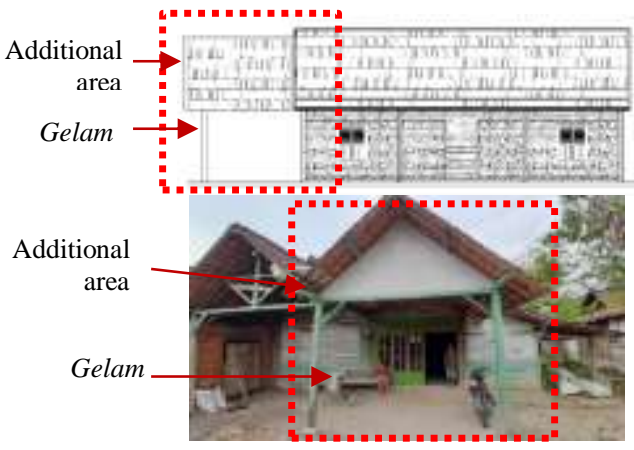

Figure 14. Front view of Pardji's house

Furthermore, gelam known as wooden planks is used as the walls of the house, with a new addition at the front, as shown in figure 14 .

Also, fire stove is used as cooking tool, but it is very rare, especially in rural areas. Based on the results of interviews with homeowners, the use of this stove is much safer than using a $3 \mathrm{~kg}$ LPG gas cylinder.

\section{House 6: Suratun}

Figure 15 showed the house plan of the Suratun, with no changes in its spatial form. Before 2017, gelam was used on all sides of the house, but was replaced with a calciboard wall. According to Suratun, several years ago, there was assistance from the government for livable houses, which resulted to converting wooden planks into calciboard, hence, this replacement is not the will of the owner. However, the walls that were expected to be more durable and better, are now broken and bumpy as shown in figure 16 .

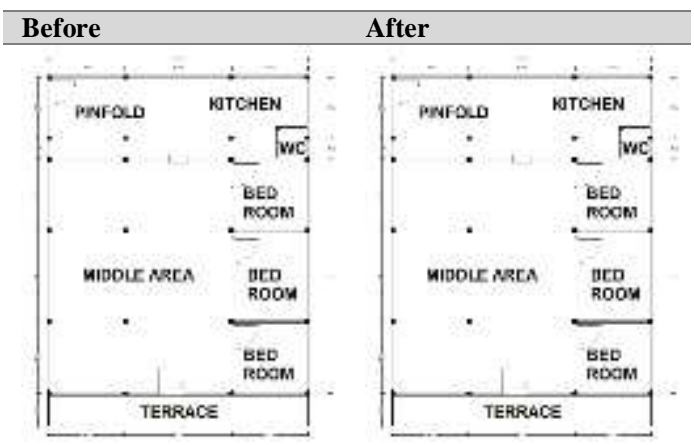

Figure 15. Comparison of Suratun's house plans 


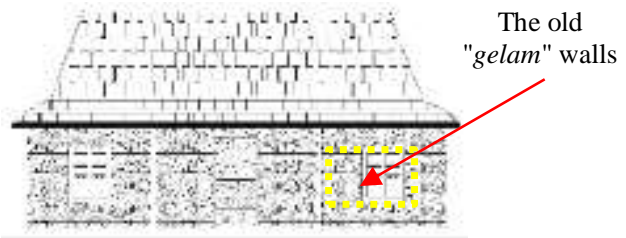

(a)

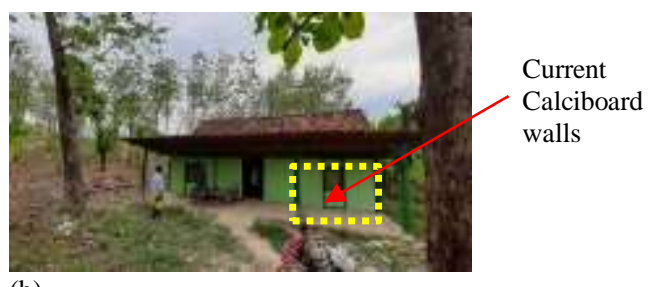

(b)

Figure 16. (a) Reconstruction of srotong house; (b) Front view of Suratun's house

It is therefore unfortunate that the local government, expected to preserve the authenticity of the Samin community's srotong houses, has changed it with more modern materials which does not have any positive impact on home owners.

3. Analysis of physical transformation based on Habraken's theory

According to Habraken's theory, physical transformation is a nominal class and based on individuals. Therefore, the changes in each housing unit are influenced by the occupant's activities. The aspects of this transformation are shown in table 1.

Table 1. Habraken's classification of physical changes

\begin{tabular}{|c|c|c|}
\hline No & $\begin{array}{l}\text { Habraken } \\
\text { (1998) }\end{array}$ & Adjustments \\
\hline \multicolumn{3}{|c|}{ Nominal classes; Physical transformation } \\
\hline $\mathrm{a}$ & $\begin{array}{l}\text { Body and } \\
\text { utensils }\end{array}$ & Furniture \\
\hline $\mathrm{b}$ & Furniture & Furniture \\
\hline $\mathrm{c}$ & Partitioning & Separator field \\
\hline $\mathrm{d}$ & $\begin{array}{l}\text { Building } \\
\text { elements }\end{array}$ & Building elements \\
\hline $\mathrm{e}$ & Roads & Building outreach \\
\hline f & Major artery & The main route in the village \\
\hline
\end{tabular}

Table 2. Identification of physical transformation at Samin Blora's house

\begin{tabular}{|c|c|c|c|c|c|c|c|c|}
\hline No & $\begin{array}{l}\text { Habraken } \\
\text { (1998) }\end{array}$ & $\begin{array}{l}\text { Adjust- } \\
\text { ments }\end{array}$ & \multicolumn{6}{|c|}{ The house studied (core area group) } \\
\hline \multicolumn{3}{|c|}{$\begin{array}{l}\text { Nominal classes; the order of } \\
\text { physical transformation }\end{array}$} & $\begin{array}{l}\text { (1) } \\
\text { Lasio }\end{array}$ & $\begin{array}{l}\text { (2) } \\
\text { Marsi }\end{array}$ & $\begin{array}{l}\text { (3) } \\
\text { Jami }\end{array}$ & $\begin{array}{l}\text { (4) } \\
\text { Lapi }\end{array}$ & $\begin{array}{l}(5) \\
\text { Pardjii }\end{array}$ & $\begin{array}{l}\text { (6) } \\
\text { Suratun }\end{array}$ \\
\hline a & $\begin{array}{l}\text { Body and } \\
\text { utensils }\end{array}$ & Furniture & $\begin{array}{l}\text { The residents } \\
\text { are familiar } \\
\text { with } \\
\text { modernity. } \\
\text { They still use } \\
\text { the stove, and } \\
\text { there is } \\
\text { already a } \\
\text { toilet }\end{array}$ & $\begin{array}{l}\text { The } \\
\text { residents } \\
\text { are still } \\
\text { adaptive, } \\
\text { they still } \\
\text { use the } \\
\text { stove, there } \\
\text { is already a } \\
\text { toilet }\end{array}$ & $\begin{array}{l}\text { The } \\
\text { residents } \\
\text { are still } \\
\text { adaptive, } \\
\text { they still } \\
\text { use the } \\
\text { stove, there } \\
\text { is already a } \\
\text { toilet }\end{array}$ & $\begin{array}{l}\text { The } \\
\text { residents } \\
\text { are modern, } \\
\text { have used } \\
\text { the LPG } \\
\text { stove, still } \\
\text { use the } \\
\text { stove, and } \\
\text { there is a } \\
\text { toilet }\end{array}$ & $\begin{array}{l}\text { The } \\
\text { residents } \\
\text { are modern, } \\
\text { have used } \\
\text { the LPG } \\
\text { stove, still } \\
\text { use the } \\
\text { stove, and } \\
\text { there is a } \\
\text { toilet }\end{array}$ & $\begin{array}{l}\text { The } \\
\text { residents } \\
\text { are still } \\
\text { adaptive, } \\
\text { still using } \\
\text { the stove, } \\
\text { and there } \\
\text { is already } \\
\text { a toilet }\end{array}$ \\
\hline $\mathrm{b}$ & Furniture & Furniture & $\begin{array}{l}\text { Dominated by } \\
\text { wood, and } \\
\text { long chairs } \\
\text { are widely } \\
\text { used. The } \\
\text { wooden table } \\
\text { is elongated. }\end{array}$ & $\begin{array}{l}\text { It is } \\
\text { dominated } \\
\text { by wood, } \\
\text { chairs, } \\
\text { wooden } \\
\text { tables. } \\
\text { There is } \\
\text { limited } \\
\text { furniture }\end{array}$ & $\begin{array}{l}\text { It is } \\
\text { dominated } \\
\text { by wood, } \\
\text { chairs, } \\
\text { wooden } \\
\text { tables. } \\
\text { There is } \\
\text { limited } \\
\text { furniture }\end{array}$ & $\begin{array}{l}\text { The } \\
\text { dominance } \\
\text { of wood, } \\
\text { and already } \\
\text { using a } \\
\text { glass sofa } \\
\text { as well as } \\
\text { table. }\end{array}$ & $\begin{array}{l}\text { Dominated } \\
\text { by wood, } \\
\text { wooden } \\
\text { tables and } \\
\text { chairs, as } \\
\text { well as the } \\
\text { furniture is } \\
\text { limited }\end{array}$ & $\begin{array}{l}\text { Dominate } \\
\mathrm{d} \text { by } \\
\text { wood, } \\
\text { chairs, } \\
\text { wooden } \\
\text { tables. } \\
\text { The } \\
\text { furniture } \\
\text { is limited }\end{array}$ \\
\hline $\mathrm{c}$ & Partitioning & $\begin{array}{l}\text { Separator } \\
\text { field }\end{array}$ & $\begin{array}{l}\text { Wooden } \\
\text { planks } \\
\text { (gelam) }\end{array}$ & $\begin{array}{l}\text { Wooden } \\
\text { planks } \\
(\text { Gelam })\end{array}$ & $\begin{array}{l}\text { Wooden } \\
\text { planks } \\
\text { (gelam) }\end{array}$ & $\begin{array}{l}\text { Wooden } \\
\text { planks } \\
\text { (gelam) }\end{array}$ & $\begin{array}{l}\text { Wooden } \\
\text { planks } \\
\text { (gelam) }\end{array}$ & $\begin{array}{l}\text { Wooden } \\
\text { planks } \\
(\text { gelam })\end{array}$ \\
\hline $\mathrm{d}$ & $\begin{array}{l}\text { Building } \\
\text { elements }\end{array}$ & $\begin{array}{l}\text { Building } \\
\text { elements }\end{array}$ & $\begin{array}{l}\text { The concept } \\
\text { of a village } \\
\text { house, } \\
\text { dominated by } \\
\text { wood } \\
\text { materials, } \\
\text { brick floors } \\
\text { and wooden } \\
\text { plank walls. }\end{array}$ & $\begin{array}{l}\text { The } \\
\text { concept of } \\
\text { the Srotong } \\
\text { house, } \\
\text { dominated } \\
\text { by wood } \\
\text { materials, } \\
\text { with brick } \\
\text { floors and }\end{array}$ & $\begin{array}{l}\text { The } \\
\text { concept of } \\
\text { the Srotong } \\
\text { house, } \\
\text { dominated } \\
\text { by wood } \\
\text { materials, } \\
\text { with brick } \\
\text { floors and }\end{array}$ & $\begin{array}{l}\text { The } \\
\text { concept of } \\
\text { a village } \\
\text { house, } \\
\text { dominated } \\
\text { by wood, } \\
\text { brick walls, } \\
\text { ceramic } \\
\text { floors and } \\
\text { some clay }\end{array}$ & $\begin{array}{l}\text { The } \\
\text { concept of } \\
\text { the Srotong } \\
\text { house, } \\
\text { changes in } \\
\text { orientation, } \\
\text { dominated } \\
\text { by wood } \\
\text { materials, } \\
\text { wooden }\end{array}$ & $\begin{array}{l}\text { The } \\
\text { concept } \\
\text { of the } \\
\text { Srotong } \\
\text { house is } \\
\text { dominate } \\
\text { d by } \\
\text { wood } \\
\text { material, } \\
\text { wooden }\end{array}$ \\
\hline
\end{tabular}




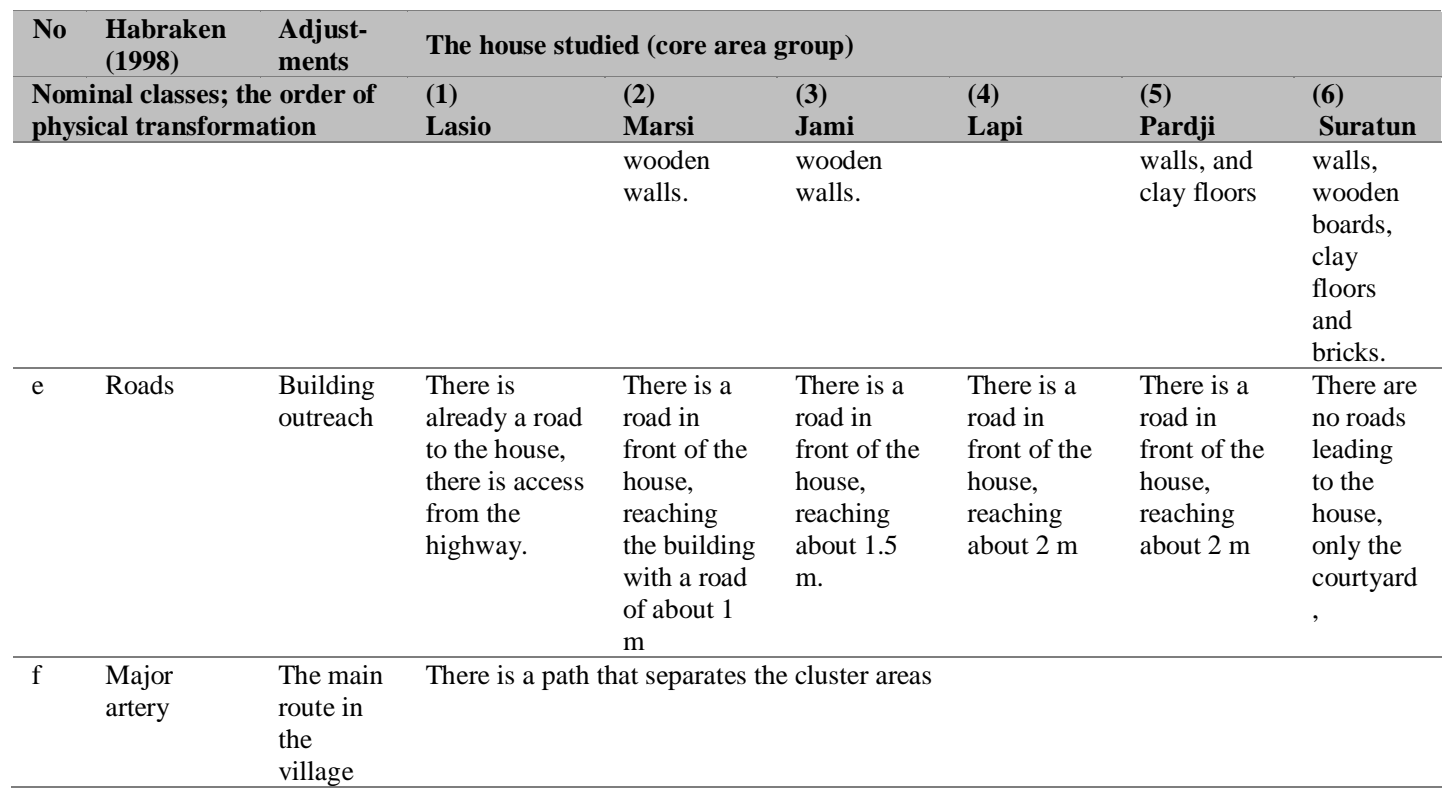

Based on table 2 above, the following was described:

a. From the body \& utensils aspect, almost all housing units still use the same type and furniture or household utensils. This indicated that the Samin community in Blora is still carrying out its traditions, such as using household furniture, namely fire stoves made of clay. Based on the interview results from informants, it is much easier to use a fire stove than using an LPG gas cylinder. Also, the use of fire stoves until now was due to the location near the teak forest.

b. Therefore, the use of wood and its processed types in the furniture aspect is still very dominant.

c. From the partitioning aspect, all housing units use gelam known as wooden planks as a wall divider between rooms.

d. From the aspect of Building Elements, on average, each housing unit uses wood as the most dominant material. Among the 7 houses studied, ceramics were used as floor covering material in only 1 unit, while bricks were used in the rest. The use of brick material is still acceptable, because it is also a form of Samin teaching which assumes that people living on earth must have their feet on the ground.

e. Aspects of the Roads. In the past, this aspect is not applied to the Samin environment because the environment became one unit with a large courtyard in the middle and only one external access road. However, after the era of development and preservation, a path was made in front of each house, therefore, the aspect of house with the road looks very achievable.

f. Major Artery Aspects. In this area, it is very clear that the regions are formed based on clusters or groups, therefore roads are connecting the group of one area with others. From the beginning, the area was small and are inhabited by several community groups. Therefore, the place was expanded by clearing the forest to occupy new houses due to the addition of family members over time.

\section{Conclusion}

Based on Habrakren's theory of physical transformation also known as the Habraken pyramid, the classification is nominal, in which the houses of the Samin community in Blora, especially in the core area, still use many cultural elements such as physical and non-physical. However, this study showed that the physical element is more dominant.

Among the six aspects of Habraken, the body $\&$ utensil, and the Building Elements are the most dominant aspects that showed changes in each object studied. Furthermore, the changes that occurred in the facades are for the shape of the building with existing materials. For example, when straw is used as the roof, it has to be replaced frequently instead of using clay tiles. 
Each house studied has characteristics that are divided into 3 areas, namely front, center, and back. The front is generally used as a terrace and an empty area, while the middle area is used as a bedroom, and the back is used as a kitchen, bathroom, and livestock pen.

Conclusively, among the 6 objects studied, glass materials were used in 2 houses, while ceramic materials were used in only 1 as the floor coverings. Hence, this phenomenon was influenced by modernity elements applied by the residents.

\section{References}

Bawole, Paulus. 2020. 'Pengembangan Kampung Kota Sebagai Salah Satu Alternatif Tujuan Wisata Minat Khusus'. ARTEKS: Jurnal Teknik Arsitektur 5 (1): 115-26. https://doi.org/10.30822/arteks.v5i1.362.

Bukit, Elya Santa, Himasari Hanan, and Arif Sarwo Wibowo. 2012. 'Aplikasi Metode N. J. Habraken Pada Studi Transformasi Permukiman Tradisional'. Jurnal Lingkungan Binaan Indonesia (JLBI) 1 (1): 51-62. https://jlbi.iplbi.or.id/wpcontent/uploads/2012/07/V1N1-p051-p062Aplikasi-Metoda-N.J.-Habraken-pada-StudiTransformasi-Permukiman-Tradisional.pdf.

Dakung, Sugiarto. 1982. Arsitektur Tradisional Daerah Istimewah Yogyakarta. Yogyakarta: Departemen Pendidikan dan Kebudayaan, Kebudayaan Daerah Yogyakarta.

Habraken, N. John. 1998. The Structure of the Ordinary, Form and Control in the Built Environment. Edited by Jonathan Teicher. Paperback. Cambridge: MIT Press. https://www.habraken.com/html/structure_of _the_ordinary.htm.

Huda, Khoirul, and Anjar Mukti Wibowo. 2013. 'Interaksi Sosial Suku Samin Dengan Masyarakat Sekitar (Studi Di Dusun Jepang Desa Margomulyo Kecamatan Margomulyo Kabupaten Bojonegoro Tahun 1990-2012)'. AGASTYA: JURNAL SEJARAH DAN PEMBELAJARANNYA 3 (01). https://doi.org/10.25273/ajsp.v3i01.907.

Munawaroh, Siti, Christriyati Ariani, and Suwarno. 2015. Etnografi Masyarakat Samin Di Bojonegoro (Potret Masyarakat Samin Dalam Memaknai Hidup). Yogyakarta: Balai Pelestarian Nilai Budaya (BPNB)
Yogyakarta.

http://repositori.kemdikbud.go.id/1146/1/Etn ografi Masyarakat Samin di Bojonegoro_LR.pdf.

Mustinda, Lusiana. 2021. 'Suku Samin, Masyarakat Adat Dari Pedalaman Blora Yang Memiliki Nilai Luhur'. DetikEdu. 2021. https://www.detik.com/edu/detikpedia/d5523629/suku-samin-masyarakat-adat-daripedalaman-blora-yang-memiliki-nilai-luhur.

Pangarso, FX. Budiwdodo, Roni Sugiarto, and Anastasia Anindyasarathi. 2017. 'Pendekatan Desain Arsitektur Di Indonesia Dalam Menghadapi Fenomena Perkembangan Teknologi Di Awal Abad XXI'. Universitas Katolik Parahyangan. 2017. https://unpar.ac.id/pendekatan-desainarsitektur-di-indonesia-dalam-menghadapifenomena-perkembangan-teknologi-di-awalabad-xxi/.

Poerwanto, Endy. 2019. 'Samin Ditetapkan Warisan Budaya Tak Benda Indonesia'. Bisniswisata.Co.Id. 2019. https://bisniswisata.co.id/samin-ditetapkanwarisan-budaya-tak-benda-indonesia/.

Purnomo, Heri. 2017. 'Masyarakat Samin Mulai Terbuka Dengan Teknologi'. INewsJateng, 23 November 2017. https://jateng.inews.id/berita/masyarakatsamin-mulai-terbuka-dengan-teknologi.

Rapoport, Amos. 1983. 'Development, Culture Change and Supportive Design'. Habitat International 7 (5-6): 249-68. https://doi.org/10.1016/0197-3975(83)900760 .

Rosyid, Moh. 2010. Kodifikasi Ajaran Samin. 1st ed. Sleman, Yogyakarta: Kepel Press.

Sachari, Agus, and Yan Yan Sunarya. 2001. Desain Dan Dunia Kesenirupaan Indonesia Dalam Wacana Transformasi Budaya. Bandung: ITB Press.

Sardjono, Agung Budi, and Satrio Nugroho. 2015. 'Keragaman Perubahan Pada Rumah Tradisional Jawa Di Pedesaan'. Modul 15 (2): 141-56. https://doi.org/https://doi.org/10.14710/mdl.1 5.2.2015.141-156.

Sawunggaling, Danik. 2020. 'Suku Samin Desa Klopoduwur Blora'. Indonesia. https://www.youtube.com/watch?v=hWLXp SHVS6A.

Sesotyaningtyas, Mega, Wiwik Dwi Pratiwi, and Jawoto Sih Setyono. 2015. 'Transformasi Hunian Dengan Perspektif Spasial Dan 
Tatanan Budaya: Komparasi Permukiman Kumuh Bang Bua, Thaildan Dan Kampung Naga, Indonesia'. Geoplanning: Journal of Geomatics and Planning 2 (2). https://doi.org/10.14710/geoplanning.2.2.116 $-123$.

Sri Pinasti, V. Indah, and Puji Lestari. 2018. 'Masyarakat Samin Ditinjau Dari Sejarah Dan Nilai-Nilai Pendidikan Karakter'. ISTORIA: Jurnal Pendidikan Dan Ilmu Sejarah 13 (2). https://doi.org/10.21831/istoria.v13i2.17737.

Subroto, Tarcicius Yoyok Wahyu. 2019. 'Koeksistensi Alam Dan Budaya Dalam Arsitektur'. ARTEKS: Jurnal Teknik Arsitektur 3 https://doi.org/10.30822/arteks.v3i2.60.

Sugiyono. 2019. Metode Penelitian Kuatintatif, Kualitatif Dan R\&D. Alfabeta. 2nd ed. Bandung: Alfabeta. https://doi.org/2008.

Tjahjono, Gunawan. 1983. 'Cosmos, Center Dan Duality in Javanese Architectural Tradition the Symbolic Dimensions of House Shapes in Kota Gede Dan Surrounding'. Berkeley, California: Ann Arbor, Michigan : University Microfilms International.

Widodo, Johannes. 2019. 'Human, Nature, And Architecture'. ARTEKS: Jurnal Teknik
Arsitektur
3
(2):
$145-48$. https://doi.org/10.30822/arteks.v3i2.65.

Zuchdi, Darmiyati. 2009. Pendidikan Karakter: Grand Design Dan Nilai-Nilai Target. Yogyakarta: UNY Press. http://library.fip.uny.ac.id/opac/index.php?p= show_detail\&id=5003.

\section{Author(s) contribution}

Badrut Anggara Putra contributed to the research concepts preparation, methodologies, investigations, data analysis, visualization, articles drafting and revisions.

Agung Budi Sarjono contribute to the research concepts preparation and literature reviews, data analysis, of article drafts preparation and validation.

Edward Endrianto Pandelaki contribute to methodology, supervision, and validation. 